\title{
A Study of the Energy Efficiency Management in Green Standard for Energy and Environmental Design (G-SEED)-Certified Apartments in South Korea
}

\author{
Hyemi Kim@ and Wonjun Park * \\ Department of Architectural Engineering, Kangwon National University, 346 Jungang-ro, \\ Samcheok-si, Kangwon-do 25913, Korea; green_architecture@kangwon.ac.kr \\ * Correspondence: wjpark@kangwon.ac.kr; Tel.: +82-10-9377-0864
}

Received: 14 August 2018; Accepted: 22 September 2018; Published: 25 September 2018

check for updates

\begin{abstract}
With an increase in the number of Green Standard for Energy and Environmental Design (G-SEED)-certified apartments in South Korea, people are receiving incentives from the government to purchase them. Since 2013, many benefits for G-SEED-certified buildings have been offered, such as tax reductions and deregulation of building codes/guidelines. As beneficial incentives are granted to G-SEED-certified buildings, follow-up management of the buildings is also necessary. However, to date, there are no appropriate follow-up management systems or legal regulations for G-SEED-certified buildings. Buildings that are certified by G-SEED in Korean housing buildings account for $6.25 \%$ of Korea's total area. In addition, G-SEED certification has been obtained for more than $20 \%$ of the total completed housing area (2014-2017). Therefore, the energy efficiency-management of G-SEED certified buildings is also very important economically for reducing greenhouse gas emissions. In this study, domestic and foreign energy efficiency follow-up management systems were analyzed, and the amount of energy that is used by apartment houses with incentives was investigated. We have identified problems with the G-SEED system by analyzing evaluation methods, evaluation items, and points of G-SEED certification in related research studies. We also compared the energy consumption of an apartment building with G-SEED certification with that of adjacent complexes, thereby applying original research methods. The results show that energy use in G-SEED-certified buildings was not efficient. Accordingly, the study confirms that continuous management after G-SEED certification by establishing a follow-up management system is needed. In this study, domestic and foreign follow-up management systems were compared, problems with the apartment housing information management system run by the government were examined, and improvement measures were suggested.
\end{abstract}

Keywords: G-SEED; apartment; energy efficiency; facility management; post management; green building certification

\section{Introduction}

Greenhouse gases have negative effects that affect global climate change, energy security, and the economy, among others [1-3]. Recognizing the need for countermeasures to deal with greenhouse gas reduction policies and climate change, major countries, such as European Union (E.U.) countries, the United States of America (U.S.A.), the United Kingdom (U.K.) Japan, and China, are adopting greenhouse gas reduction policy packages, although at different rates and intensities [2].

The amount of greenhouse gas emissions in the building sector accounts for $25 \%$ of worldwide greenhouse gas emissions [3]. The building sector is considered to be the sector that requires the lowest 
investment to reduce greenhouse gases, while offering the highest reduction potential [4-6]. Therefore, the management of building greenhouse gas emissions is very important.

Most developed countries have declared mandatory zero-energy housing targets by around 2020 (E.U.: 2021; U.K.: 2016; and, U.S.A.: 2030) and they are establishing roadmaps and execution plans through linkages among policies, technologies, and markets [7]. Major policies that are relevant to architecture include the strengthening of energy saving standards, which enforce energy savings during all stages-from design to the construction and use of new buildings and mandatory zero-energy buildings. Furthermore, energy efficiency grade certifications, environmentally friendly building certification policies, and environmental labels are applied to ensure environmentally friendly and sustainable buildings.

In South Korea, specific medium- and long-term greenhouse gas emissions forecasting for the building sector and reduction analysis models have not yet been developed. Furthermore, although greenhouse gas reduction technology databases and reduction model compositions are underway from the perspective of national energy supply and demand, their utilization is limited [2]. Particularly, research and development on greenhouse gas reduction technology applications and green-remodeling technology are insufficient with respect to existing buildings, which have relatively high greenhouse gas reduction potentials. Therefore, in order to manage the greenhouse gas emissions of the South Korean building sector, verification of the actual energy utilized by Green Standard Energy and Environmental Design (G-SEED)-certified buildings will be need to verify consumption management and efficiency improvement.

During our literature review, we identified studies that investigated the satisfaction of residents living in apartments certified as green buildings [8,9], developed an evaluation process for G-SEED [10], clarified the importance of energy efficiency and environmental performance management in order to improve the life span of buildings [11,12], and analyzed the relationship between residents' behavior and the energy performance of buildings $[13,14]$. Additionally, there was research on the use of life cycle assessments on G-SEED-certified buildings [15], a comparison of the G-SEED and Leadership in Energy and Environmental Design (LEED) energy performance, comparative analysis of green building certification programs and evaluation methods in the international community [16-18], and an analysis of green building standards and certification systems, as well as their economic effects in different countries [19-22]. However, we only found one study that evaluates the energy efficiency in G-SEED-certified buildings relative to the average energy usage in nearby buildings and areas under similar conditions.

G-SEED is a representative green building certification program in South Korea that evaluates the eco-friendliness of a building in terms of measures that are undertaken to improve its environmental performance while reducing the environmental load of the building, e.g., reducing energy consumption and carbon dioxide emissions of buildings [23]. Furthermore, if grade 2 or higher is assigned in the G-SEED certification or an $80 \%$ or higher score is achieved in the energy performance evaluation during the energy efficiency grade certification, incentives, such as tax reductions and floor area ratio mitigation, are granted [4].

When the number of completely constructed apartment houses and houses with G-SEEDcertification for the last 10 years was examined, the number of completely constructed apartment houses was found to have increased continuously from 2011. The number of G-SEEDcertified apartment houses also continuously increased from 2005 [23].

Residential buildings had the highest ratio of total floor area among different building usages in South Korea (48\% in 2015) [24]. Furthermore, residential buildings account for the highest ratio of G-SEED-certified buildings (34.12\%), with apartment buildings receiving the most G-SEED certificates at $31.21 \%$ (2002-2016) [20]. Therefore, in this study, we are investigating G-SEED-certified apartment buildings. Since the disclosure of the energy consumption in apartments with 300 households or more is obligatory, we focus our analysis primarily on buildings that meet that criterion. Korean apartment energy usage is disclosed in the "Apartment management information system (AMIS)" [25]. 
As G-SEED certification has been made compulsory, follow-up management of buildings with G-SEED has become important. In particular, the number of G-SEED-certified buildings rapidly increased since 2013, when the incentive system was initiated [23]. However, systems to manage buildings after certification are insufficient, and legal regulations on follow-up management are lacking [26,27]. It is impossible to confirm whether the energy savings is actually a result of the process of G-SEED certification

This study aims to analyze the amount of energy that is used by apartments in apartment buildings in South Korea, which have obtained G-SEED certification and made use of incentives, and examines the energy efficiency in terms of follow-up management. Furthermore, to identify problems with the follow-up management system, the AMIS of South Korea is compared with those of other countries, and an improvement method is proposed.

\section{Theoretical Consideration}

\subsection{Green Building Certification System in South Korea}

G-SEED is a system that certifies environmentally friendly architecture in South Korea. It assesses and certifies a building's eco-friendliness to reduce the environmental load of the building and enhance environmental functions, for instance, decreasing the energy use and carbon dioxide emissions of the building. The certification parameters are different depending on the use of the building. The G-SEED certification examination sets standards for apartment houses, which are categorized into a total of eight areas [21]. The assigned score of the energy and environmental pollution areas is 21 points, which becomes 25 points when weighting is applied. Energy performance corresponds to 14.3 points for a perfect score when weighting is applied.

Energy conservation is evaluated on the basis of points that are obtained through the energy performance index examination of a building's energy saving design standard (assigned by the Ministry of Land, Infrastructure, and Transport (MOLIT)) or its energy efficiency certification grade. The energy efficiency grade is an assessment item of G-SEED and is obligatory at the actual energy use stage.

Therefore, to investigate the energy efficiency of apartment houses, the effectiveness of follow-up management can be analyzed if the predicted energy efficiency at the unit planning stage is compared to the present energy performance in the building.

\subsection{Management of Efficient Energy Systems Internationally}

Table 1 shows the differences in energy efficiency certification systems between South Korea and Europe, the U.S.A., and Japan. These countries were designated by the Kyoto Protocol (1995) to establish agencies for greenhouse gas reduction obligations. Therefore, a system to reduce greenhouse gas emissions was established earlier in these countries than in other countries (Energy star: 1994 [28,29], CASBEE: 2001 [30], and EPBD: 2002 [4-6,31,32]). Due to the institution of these systems, problems could be promptly presented and investigated as they occurred. While energy efficiency in Europe is continuously managed during various stages of building use, energy efficiency in the U.S.A., Japan, and South Korea is only planned and certified. 
Table 1. Energy efficiency management systems internationally and in South Korea.

\begin{tabular}{|c|c|c|c|c|c|}
\hline & \multicolumn{3}{|c|}{ Management of Efficient Energy Systems Internationally } & \multicolumn{2}{|c|}{$\begin{array}{c}\text { Management of Efficient Energy Systems in } \\
\text { South Korea }\end{array}$} \\
\hline Classification & $\begin{array}{l}{ }^{*} \text { Europe } \\
\text { The Energy } \\
\text { Performance of } \\
\text { Buildings Directive } \\
{[4-6,31,32]}\end{array}$ & $\begin{array}{l}\text { U.S.A. } \\
\text { Energy Star }[28,29]\end{array}$ & $\begin{array}{l}\text { Japan } \\
\text { Comprehensive } \\
\text { Assessment System for } \\
\text { Built Environment } \\
\text { Efficiency [30] }\end{array}$ & $\begin{array}{l}\text { Green Standard for } \\
\text { Energy and } \\
\text { Environmental } \\
\text { Design [23] }\end{array}$ & $\begin{array}{l}\text { Building Energy } \\
\text { Efficiency Certification } \\
\text { System [1] }\end{array}$ \\
\hline Target & All building types & $\begin{array}{l}\text { Residential and } \\
\text { non-residential } \\
\text { buildings }\end{array}$ & $\begin{array}{l}\text { Offices, schools, sales } \\
\text { facilities, restaurants, } \\
\text { meeting facilities, } \\
\text { factories, hospitals, } \\
\text { hotels, residential }\end{array}$ & $\begin{array}{l}\text { Common houses, } \\
\text { complex buildings } \\
\text { (residential), } \\
\text { business buildings, } \\
\text { hotels, sale facilities, } \\
\text { schools }\end{array}$ & $\begin{array}{l}\text { Apartments and } \\
\text { commercial buildings }\end{array}$ \\
\hline $\begin{array}{l}\text { Range for } \\
\text { evaluation }\end{array}$ & $\begin{array}{l}\text { Energy performance, } \\
\text { building hardware } \\
\text { for improving } \\
\text { housing efficiency }\end{array}$ & $\begin{array}{l}\text { Evaluation of overall } \\
\text { performance of building }\end{array}$ & $\begin{array}{l}\text { Evaluation of } \\
\text { environmental } \\
\text { performance of building }\end{array}$ & $\begin{array}{l}\text { Evaluation of overall } \\
\text { performance of } \\
\text { building }\end{array}$ & Energy reduction rate \\
\hline $\begin{array}{l}\text { Evaluation } \\
\text { items }\end{array}$ & $\begin{array}{l}\text { 1. Building } \\
\text { energy efficiency } \\
\text { Ways that can } \\
\text { improve the } \\
\text { efficiency } \\
\text { of housing }\end{array}$ & $\begin{array}{ll}\text { 1. } & \begin{array}{l}\text { Sustainable } \\
\text { site planning }\end{array} \\
\text { 2. } & \text { Efficient water use } \\
\text { 3. } & \begin{array}{l}\text { Energy } \\
\text { and atmosphere }\end{array} \\
\text { 4. } & \begin{array}{l}\text { Materials } \\
\text { and resources }\end{array} \\
\text { 5. } & \begin{array}{l}\text { Quality of } \\
\text { indoor environment }\end{array} \\
\text { 6. } & \begin{array}{l}\text { Innovation } \\
\text { certainty and } \\
\text { design process }\end{array} \\
\text { 7. } & \text { Regional characteris }\end{array}$ & $\begin{array}{ll}\text { 1. } & \text { Environmental } \\
\text { quality } \\
\text { performance, } \\
\text { indoor } \\
\text { environment, } \\
\text { service } \\
\text { performance, } \\
\text { outdoor environment } \\
\text { 2. } \begin{array}{l}\text { Reduction of } \\
\text { environmental }\end{array} \\
\text { impact, energy, } \\
\text { resources, } \\
\text { materials, } \\
\text { site environment }\end{array}$ & $\begin{array}{ll}\text { 1. } & \begin{array}{l}\text { Land use and } \\
\text { transport action }\end{array} \\
\text { 2. } & \text { Energy } \\
\text { and pollution } \\
\text { 3. } & \text { Materials and } \\
\text { resource s } \\
\text { 4. } & \text { Water } \\
\text { 5. } & \text { Management } \\
\text { 6. } & \text { Ecology } \\
\text { 7. } & \\
\text { 8. } & \\
& \text { Building perforn environm }\end{array}$ & $\begin{array}{l}\text { 1. Analysis of } \\
\text { "primary energy } \\
\text { requirements per } \\
\text { annual unit area", } \\
\text { such as air } \\
\text { conditioning, hot } \\
\text { water supply, } \\
\text { lighting, ventilation } \\
\text { ant } \\
\text { ance }\end{array}$ \\
\hline $\begin{array}{l}\text { Certification } \\
\text { grade }\end{array}$ & Not classified & 4 grades & 5 grades & 4 grades & 10 grades \\
\hline
\end{tabular}

The Energy Performance of Buildings Directive (EPBD) of Europe manages the actual amount of energy used for all buildings. However, in the cases of Energy Star in the U.S.A., the Comprehensive Assessment System for Built Environment Efficiency in Japan, and G-SEED in South Korea, the applicable types of buildings are limited when compared to Europe, and the evaluation ratio for energy efficiency is low, as there are various evaluation items. The Building Energy Efficiency Certification System of South Korea is similar to the EPBD of Europe, but, as there is no compulsory program for post-certification management, the management of energy efficiency in buildings is practically non-existent.

\section{Analysis of Energy Efficiency during Management in G-SEED-Certified Apartments}

\subsection{Outline of Energy Efficiency Analysis}

\subsubsection{Process of Unit Selection}

As the state of energy consumption during actual use is required for follow-up management of the energy efficiency of apartment houses with G-SEED units, which were completely constructed and occupied, these buildings were examined. Figure 1 shows the process of obtaining information on buildings that are certified on the official G-SEED website operated by the MOLIT [20].

In particular, six different units in South Korea were selected for investigation after three stages of selection from units that had received incentives, as shown in Table 2. 
Table 2. Selection process of six different units in South Korea.

\begin{tabular}{clc}
\hline & \multicolumn{1}{c}{ Selection Criteria of Target Area } & Selected Area \\
\hline Level 1 & $\begin{array}{l}\text { - Green Standard of Energy and Environmental Design main certification area } \\
\text { - Benefits of incentive received }\end{array}$ & 77 \\
\hline Level 2 & $\begin{array}{l}\text { - No townhouse or multiplex house types } \\
\text { - No dormitory or office housing }\end{array}$ & 24 \\
\hline Level 3 & $\begin{array}{l}\text { - Three years after completion of the building } \\
\text { - Current energy consumption is disclosed, as is the energy consumption analysis area }\end{array}$ & 6 \\
\hline
\end{tabular}
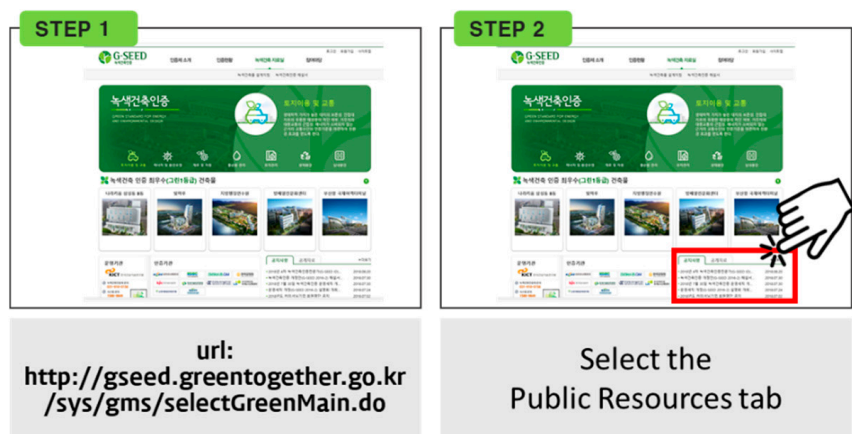

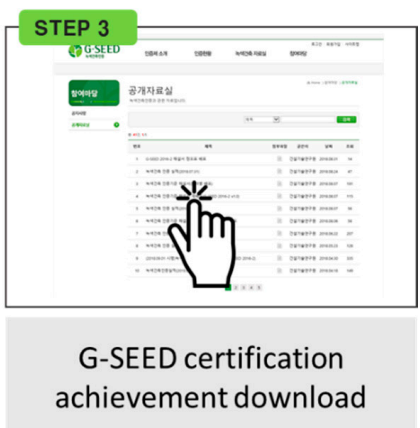

Figure 1. Acquisition process of building information certified by Green Standard for Energy and Environmental Design (G-SEED).

A building that was over three years old since its completion was selected, because the energy consumption survey of buildings after one year of completion showed that the energy usage evaluation is insufficient due to the unsold or unoccupied housing [33,34].

Figure 2 shows the regional G-SEED certification status and the locations of the relevant units; Unit A is located in Incheon city, unit D is in Sejong city, and the rest are in Paju and Suwon city in Gyeonggi-do. In the survey target unit, many regions had G-SEED certifications, including apartments in Seoul, but these were excluded for being within just three years of completion. There are only six unit survey targets, but, since all six units belong to regions with many G-SEED certificates, we propose that this number is sufficient to consider problems with G-SEED authentication through energy consumption analysis.
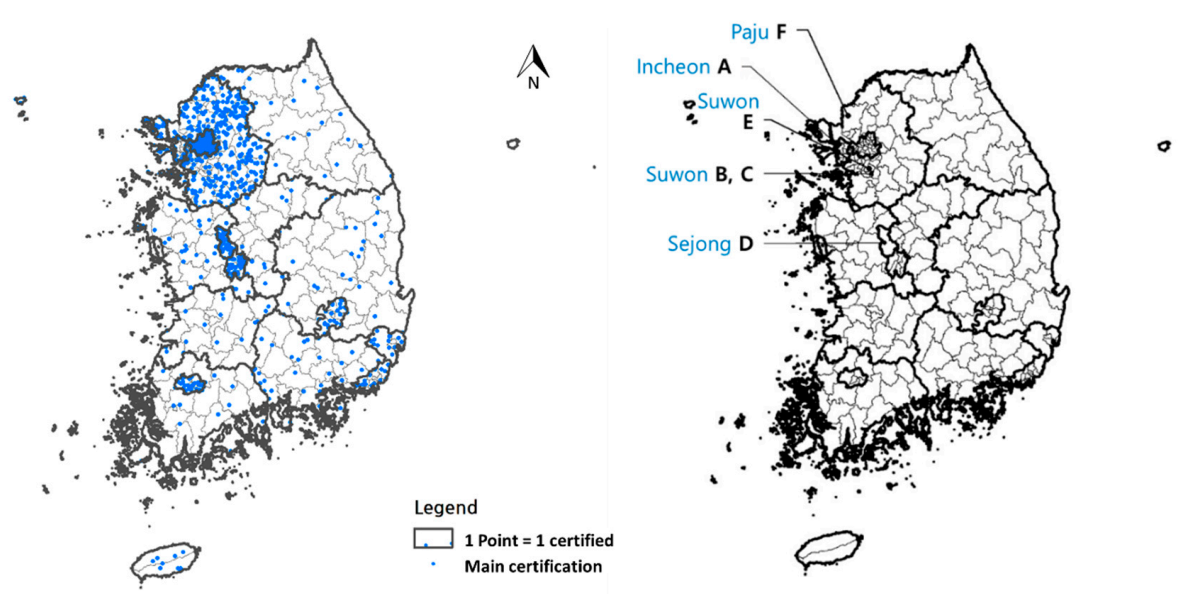

Figure 2. Regional G-SEED certification status and location of the six units in South Korea.

Table 3 summarizes the selected units. All six units had the same corridor type and heating system, and they had received various incentives depending on the preliminary certification grade [25].

The six units that were analyzed obtained good grades both in the preparatory and primary G-SEED certification. In the examination of the energy efficiency grade, unit D scored first grade, 
units A, E, and F scored second grade, and units B and C scored third grade. To obtain the incentive, an energy efficiency grade of second or higher must be acquired, or more than 80 points must be acquired on the energy saving design standard energy performance index; units $B$ and $C$ fell under this category.

All six units chose to obtain real-time transmission of data regarding the consumption of local heating, electrical fees, and others, through remote management, and all units adopted a district heating system. Figure 3 shows the regional boundaries for comparison of the geographic details of the selected unit.

Table 3. Summary of the six units examined in the study.

\begin{tabular}{|c|c|c|c|c|c|c|c|}
\hline \multicolumn{2}{|l|}{ Unit } & $\mathbf{A}$ & B & $\mathrm{C}$ & D & $\mathbf{E}$ & $\mathbf{F}$ \\
\hline \multicolumn{2}{|c|}{ Corridor type } & Stair-type & Stair-type & Stair-type & Stair-type & Stair-type & Stair-type \\
\hline \multicolumn{2}{|c|}{ Heating system } & $\begin{array}{l}\text { District } \\
\text { heating }\end{array}$ & $\begin{array}{l}\text { District } \\
\text { heating }\end{array}$ & $\begin{array}{l}\text { District } \\
\text { heating }\end{array}$ & $\begin{array}{l}\text { District } \\
\text { heating }\end{array}$ & $\begin{array}{l}\text { District } \\
\text { heating }\end{array}$ & $\begin{array}{l}\text { District } \\
\text { heating }\end{array}$ \\
\hline \multicolumn{2}{|l|}{ Incentive } & $\begin{array}{l}\text { Acquisition } \\
\operatorname{tax}\end{array}$ & $\begin{array}{l}\text { Floor area } \\
\quad \text { ratio }\end{array}$ & $\begin{array}{l}\text { Acquisition } \\
\operatorname{tax}\end{array}$ & $\begin{array}{c}\text { Value } \\
\text { added tax }\end{array}$ & $\begin{array}{l}\text { Acquisition } \\
\operatorname{tax}\end{array}$ & $\begin{array}{l}\text { Acquisition } \\
\operatorname{tax}\end{array}$ \\
\hline \multirow{2}{*}{$\begin{array}{c}\text { Rating of Green Standard } \\
\text { of Energy and } \\
\text { Environmental Design } \\
\text { certification }\end{array}$} & $\begin{array}{c}\text { Energy } \\
\text { efficiency grade }\end{array}$ & 2nd grade & 3rd grade & 3 rd grade & 1st grade & 2nd grade & 2nd grade \\
\hline & $\begin{array}{c}\text { Main } \\
\text { certification }\end{array}$ & $\begin{array}{l}\text { Green 2nd } \\
\text { grade }\end{array}$ & $\begin{array}{l}\text { Green 2nd } \\
\text { grade }\end{array}$ & $\begin{array}{l}\text { Green 2nd } \\
\text { grade }\end{array}$ & $\begin{array}{l}\text { Green 2nd } \\
\text { grade }\end{array}$ & $\begin{array}{l}\text { Green } 2 \text { nd } \\
\text { grade }\end{array}$ & $\begin{array}{l}\text { Green 2nd } \\
\text { grade }\end{array}$ \\
\hline \multirow{2}{*}{$\begin{array}{l}\text { Evaluation of the annual } \\
\text { energy consumption of } \\
\text { the building }\end{array}$} & $\begin{array}{l}\text { Electricity } \\
\text { power }\end{array}$ & B & - & - & - & C, D & - \\
\hline & Thermal energy & A, B & - & - & - & A & - \\
\hline
\end{tabular}

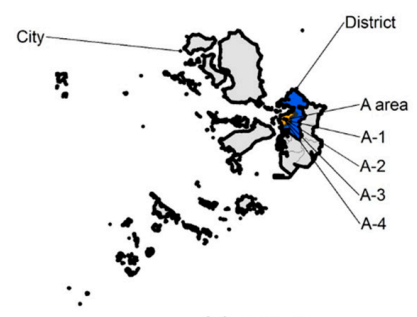

(a) A Unit

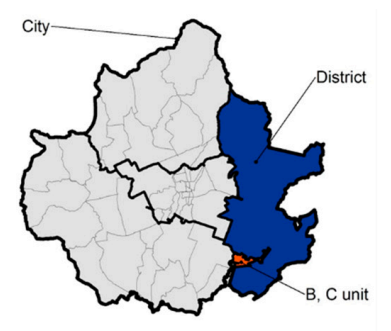

(b) B and C Unit

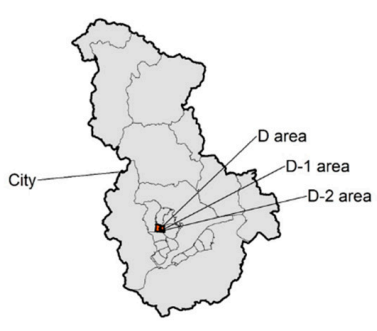

(c) D Unit

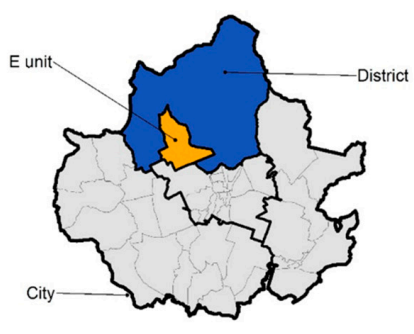

(d) E Unit

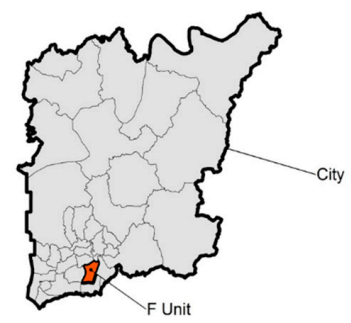

(e) F Unit

Figure 3. Geographic details of the selected units in South Korea.

The compared units are located close to the surveyed subjects and were selected based on similarities in the number of households and year of construction. The location was considered to ensure the local climate impact on energy efficiency was comparable, and the number of households was chosen as a condition, since it influences the use of energy [32].

\subsubsection{Survey Content}

The AMIS is a system that is operated by the Korea Appraisal Board, with the MOLIT as the authority. About 15927 units (as of September 2018) have been registered as apartment houses nationwide. Information about their maintenance fees, maintenance and management, and warranties, 
amongst others, is available. At present, information about maintenance costs since 2012 can be accessed along with the energy consumption of the whole unit, energy consumption (won $/ \mathrm{m}^{2}$ ) of the area for exclusive use, and average energy consumption in the district where the unit is located. Moreover, the maintenance costs for common use based on the area for exclusive use, such as heating, hot-water supply, electricity, common consumption, and exclusive use in individuals' bills, are categorized.

For the energy analysis of apartment houses with G-SEED certification, the maintenance cost of each unit from the AMIS from January to December 2017 was assessed. Heating costs, hot-water costs, and electric charges, which corresponded to individual energy consumption, were analyzed, and only exclusive consumption, except for common use, was considered.

Figure 4 shows the process of investigating the energy usage of AMIS's apartments, and we investigated the average energy consumption of the city, district, and surrounding six surveyed subjects, as described above.

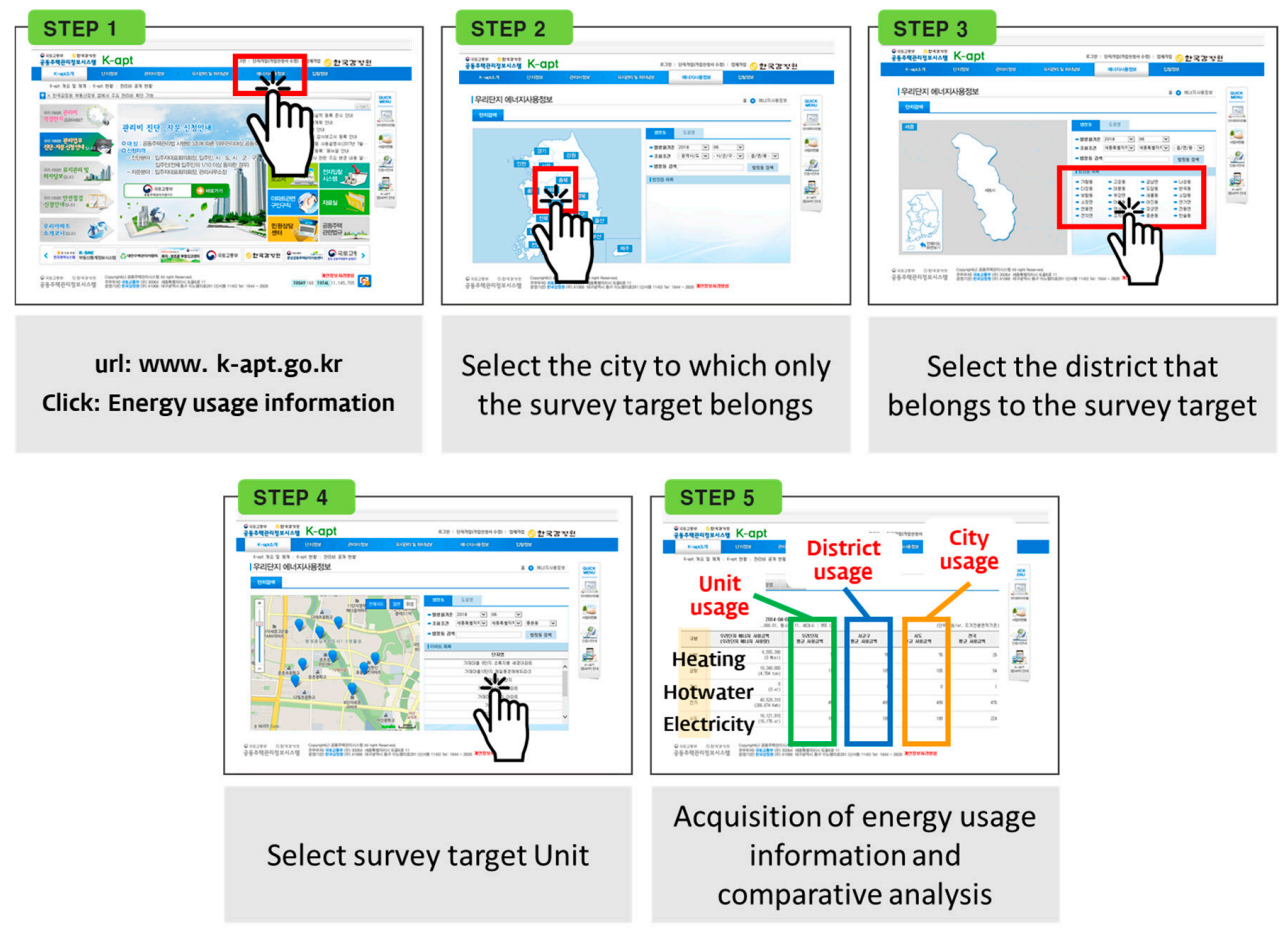

Figure 4. Energy usage information from apartment management information system (AMIS).

\subsection{Energy Efficiency Status Analysis}

Elements that determine the energy efficiency of a building are identified based on the behavior of the user, but, as users of various characteristics reside in communal housing, the energy consumption characteristics of the entire building are not determined by a specific resident; we instead analyzed it based on the total energy consumption of the building, while not considering the behavior of its individual users.

The energy consumption of unit A was lower than that of other similar units (A-1, A-2, A-3, and A-4) in terms of heating costs, hot water fees, and electricity charges. Table 4 shows the summary of four surrounding buildings to analyze the energy consumption of unit A. A-1 and A-2 had also received G-SEED certificates, but A-3 and A-4 had not. Particularly, A-1 was similar to A in terms of the number of households, height of the highest floor, and heating system. As for the corridor types, unit A was classified as stair-type, whereas the A-1 unit was classified as tower-type. When energy consumption was compared between the two units, A-1 showed especially high energy consumption, which was attributed to the difference in corridor types. A-2 consisted of a similar number of households and the 
same corridor type and heating system. As shown in Figure 5a, the heating energy consumption of the two units was similar, but A-2 used more energy for hot water, as shown in Figure 5b. Unit A used more electricity, as shown in Figure 5c. Although A-3 and A-4 used less energy for heating than unit A, their energy consumption for hot water was larger than that of unit A. Furthermore, A-3 consumed more electricity than A, whereas A-4 consumed less.

Table 4. Comparison between unit $\mathrm{A}$ and the surrounding units (A-1-A-4).

\begin{tabular}{cccccc}
\hline & A & A-1 & A-2 & A-3 & A-4 \\
\hline Completion date & 2013.05 & 2013.04 & 2012.08 & 2013.02 & 2012.08 \\
\hline Number of households & 751 & 766 & 734 & 828 & 754 \\
\hline \multirow{2}{*}{$\begin{array}{c}\text { Green Standard of Energy } \\
\text { and Environmental Design }\end{array}$} & $\begin{array}{c}\text { Main } \\
\text { certification }\end{array}$ & $\begin{array}{c}\text { Green } 2 \text { nd } \\
\text { grade }\end{array}$ & $\begin{array}{c}\text { Green } 2 \text { nd } \\
\text { grade }\end{array}$ & $\begin{array}{c}\text { Green } 2 \text { nd } \\
\text { grade }\end{array}$ & Nain \\
certification & No & No & - \\
\hline Number of floors & 57 & 57 & 30 & 42 & 30 \\
\hline Corridor type & Stair-type & Tower-type & Stair-type & Stair-type & Stair-type \\
\hline Heating system & District heating & District heating & District heating & District heating & District heating \\
\hline $\begin{array}{c}\text { Calculating ways of } \\
\text { apartment energy usage }\end{array}$ & Remote control & Remote control & Remote control & Remote control & Remote control \\
\hline Total floor area (m $\left.{ }^{2}\right)$ & $153,075.38$ & $154,318.11$ & $161,556.67$ & $197,266.51$ & $152,697.45$ \\
\hline Building-to-land ratio & $221 \%$ & $221 \%$ & $219 \%$ & $313 \%$ & $219 \%$ \\
\hline Floor area ratio & $9 \%$ & $8 \%$ & $12 \%$ & $26 \%$ & $13 \%$ \\
\hline Number of building parts & 4 & 4 & 7 & 7 & 7 \\
\hline
\end{tabular}

Therefore, the energy efficiency of unit A was not high in comparison with the energy usage of the surrounding units. Particularly, unit A showed noticeably high energy consumption patterns when compared to the city and district averages. Thus, the energy efficiency was not high, even though a G-SEED certificate was issued.

Units $B$ and $C$ belonged to zones where housing site development was expected. As there were only two units within the relevant area, only these two units could be compared. Accordingly, the data were analyzed based on the average energy consumption of the two units, city, and district. Both units scored the third grade of the energy efficiency grade certification when their construction was completed. This proved that they had low energy efficiency at the follow-up stage, as shown in Figure 6. Furthermore, the two units showed similar energy consumption for heating (Figure 6a). The average energy consumption of the district was also similar. However, when compared with the energy consumption of the cities where units B and C were located, the energy consumption of these units was higher. As shown in Figure 6b, the consumption of the two units was similar for hot water, but it was higher than the average consumption of city. Figure $6 \mathrm{c}$ shows that the electricity consumption of units B and C showed similar values, but the summer electrical energy consumption of these units was higher than the average energy consumption of the district and city. 


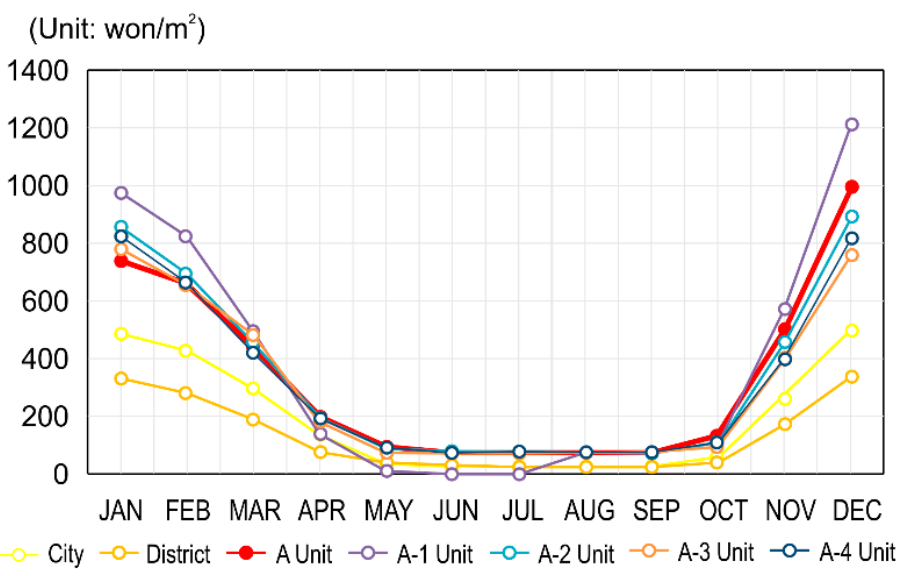

(a)

(Unit: won $/ \mathrm{m}^{2}$ )

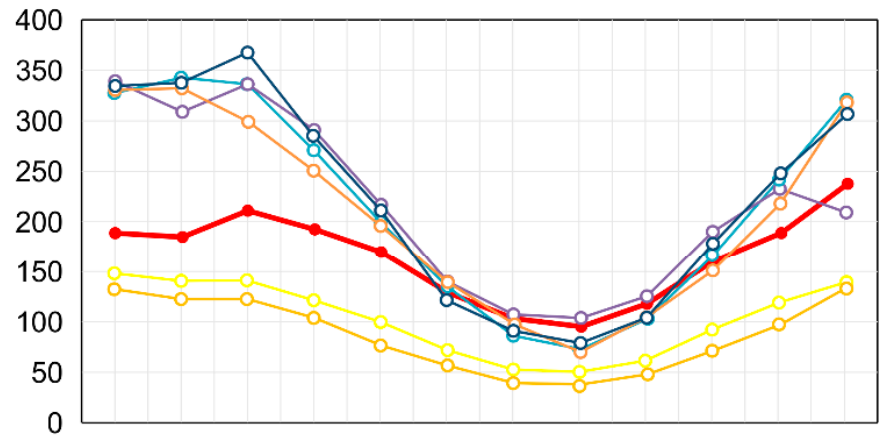

JAN FEB MAR APR MAY JUN JUL AUG SEP OCT NOV DEC

City $-O$ District $\rightarrow$ A Unit $-O-$ A-1 Unit $-O-$ A-2 Unit $-0-$ A-3 Unit $-0-$ A-4 Unit

(b)

(Unit: won $/ \mathrm{m}^{2}$ )

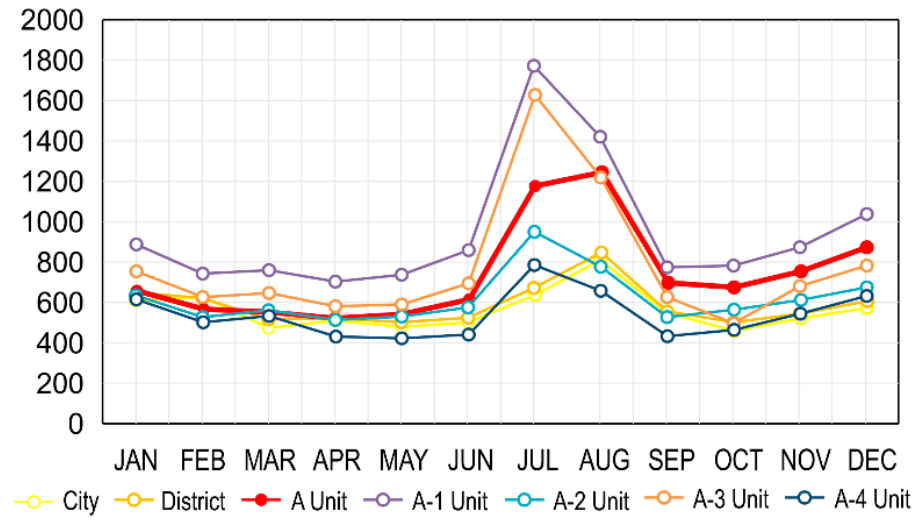

(c)

Figure 5. Energy consumption of unit A and its surrounding units. (a) Heating bills; (b) Hot water bills; and (c) Electricity bills. 


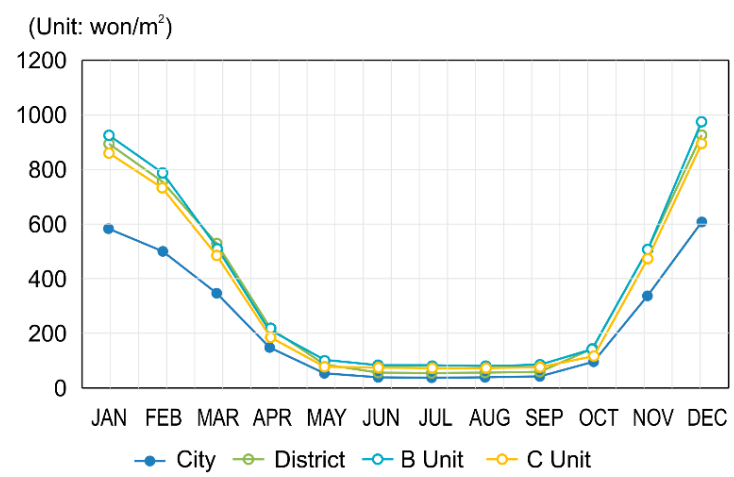

(a)

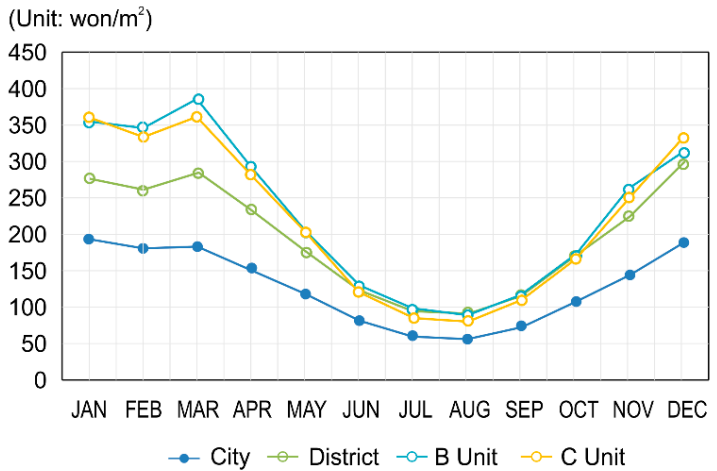

(b)

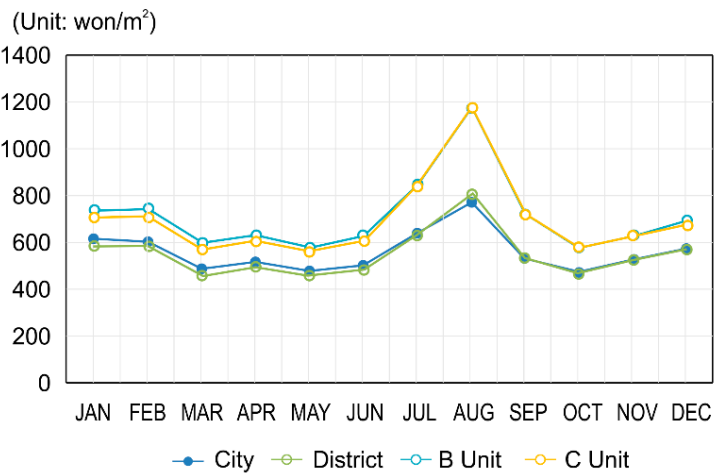

(c)

Figure 6. Energy consumption of units B and C and the surrounding units. (a) Heating bills; (b) Hot water bills; and (c) Electricity bills.

Table 5 shows the characteristics of units surrounding unit D for energy consumption comparison. D-1 did not receive G-SEED certification, but its corridor type and heating system were identical to those of unit D. Although D-2 acquired G-SEED certification, it received a lower grade than did unit D. Figure 7 shows a comparison of the energy consumption of unit D and other units for heating, electrical, and hot water energy consumption. In the energy consumption comparisons, units D, D-1, and D-2 showed higher consumption for heating than the average energy consumption of the city (Figure 7a). The energy consumption for hot water for units D and D-1 was higher than that of the city average (Figure $7 \mathrm{~b}$ ). For electricity consumption, unit D showed the lowest usage trend, and D-2 used the most energy (Figure 7c). Although unit D showed higher energy consumption values as compared to the city averages, it consumed the lowest amount when compared to the other units, followed by D-2, which received grade 3 of G-SEED. Thus, the uncertified D-1 unit consumed the largest amount of energy. 


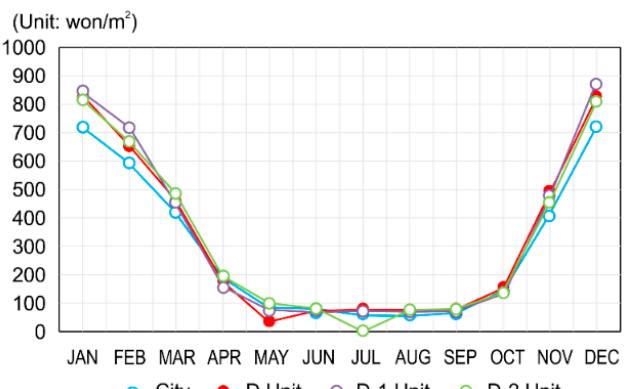

-0 - City $\rightarrow$ D Unit $-0-D-1$ Unit $-0-D-2$ Unit

(a)

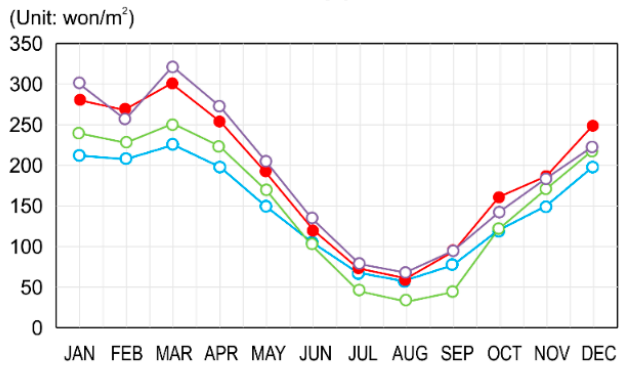

- C City $\rightarrow$ D Unit $-0-D-1$ Unit $-0-D-2$ Unit

(b)

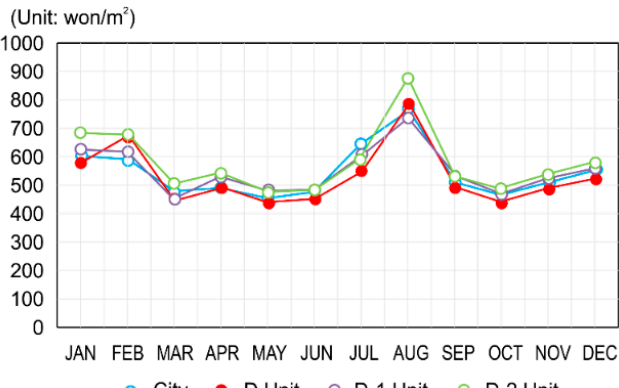

-O- City - D Unit - - D-1 Unit $\quad-0-D-2$ Unit

(c)

Figure 7. Energy consumption of unit D and surrounding units. (a) Heating bills; (b) Hot water bills; and (c) Electricity bills.

Table 5. Comparison among unit $\mathrm{D}$ and the surrounding units.

\begin{tabular}{cccc}
\hline & D & D-1 & D-2 \\
\hline Completion date & 2014.04 & 2013.12 & 2014.10 \\
Number of households & 955 & 696 & 866 \\
Green Standard of Energy and Environmental & Main certification & No & Main certification \\
Design & Green 2nd grade & - & Green 3rd grade \\
Number of floors & 29 & 15 & 30 \\
Corridor type & Stair-type & Stair-type & Stair-type \\
Heating system & District heating & District heating & District heating \\
Calculating ways of apartment energy usage & Remote control & Remote control & Remote control \\
Total floor area (m ${ }^{2}$ ) & $161,666.006$ & $92,622.9476$ & $141,411.0728$ \\
Building-to-land ratio & $172 \%$ & $154 \%$ & $177 \%$ \\
Floor area ratio & $12 \%$ & $17 \%$ & $12 \%$ \\
Number of building parts & 11 & 10 & 13 \\
\hline
\end{tabular}

The construction of unit E was completed in May 2013. It consisted of 3498 households, its corridor type was stair-type, and it had adopted the district heating method. Although attempts to select similar surrounding units that are based on the number of households and construction year were made, no comparable units were identified. Therefore, comparisons were made with the district's average energy consumption and city's average energy consumption only. Figure 8a compares the energy consumption for heating. The energy consumption of unit E was continuously higher than the average energy consumption of the district and city. Figure $8 \mathrm{~b}$ compares the energy consumption for hot water. Throughout the year, the energy consumption of unit E was higher than the average energy 
consumption of the district and city. Figure $8 \mathrm{c}$ compares the electrical energy consumption, and the energy consumption of unit $\mathrm{E}$ registered large differences when compared with the average energy consumption of the district and city.

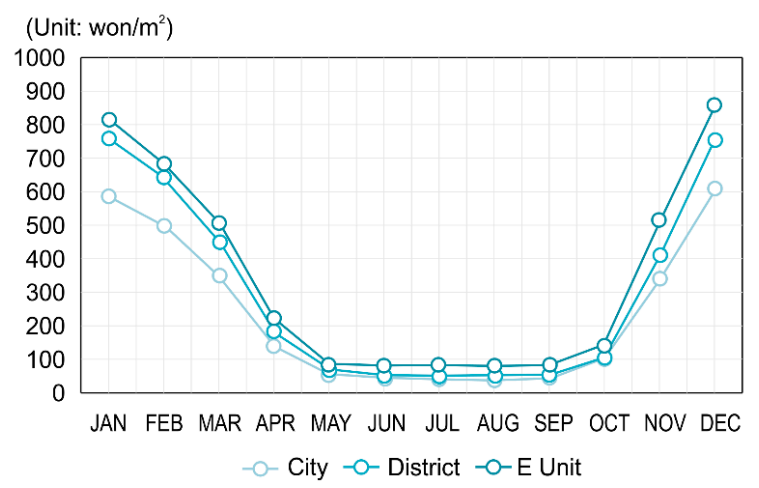

(a)

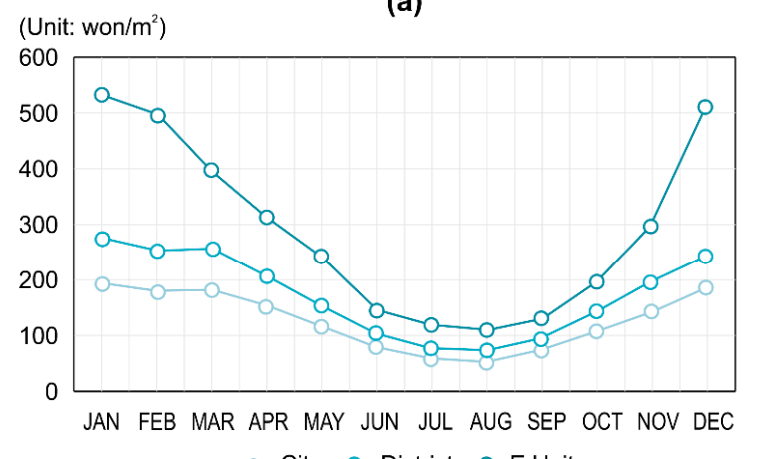

-O- City $-O-$ District $-O-E$ Unit

(b)

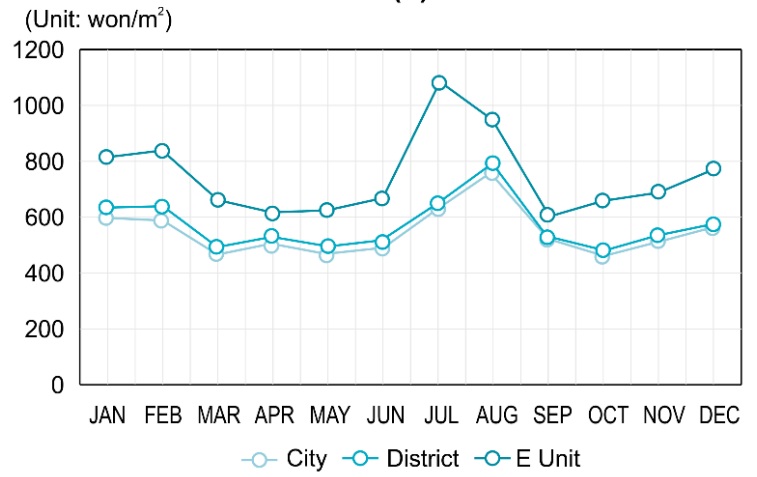

(c)

Figure 8. Energy consumption of unit E. (a) Heating bills; (b) Hot water bills; and (c) Electricity bills.

The construction of unit F was completed in November 2014. It consisted of 1880 households, its corridor type was stair-type, and it had adopted the district heating method. Although attempts to find similar surrounding units that were based on the number of households and construction year were made, no comparable units were identified. Therefore, comparisons were made with the district's and city's average energy consumption. Figure 9a shows the comparison of energy consumption for heating. When the energy consumption for January, February, March, November, and December were examined, i.e., when the temperature was low, or when it was winter in South Korea, the energy consumption of unit $\mathrm{F}$ was noticeably high. Figure $9 \mathrm{~b}$ shows the comparison of energy consumption for hot water. Throughout the year, the energy consumption of unit $\mathrm{F}$ was higher than the average energy consumption of the district and city. Figure $9 \mathrm{c}$ shows the comparison of the electrical energy consumption. The energy consumption of unit $\mathrm{F}$ showed large differences when compared with the average energy consumption of the district and city. 


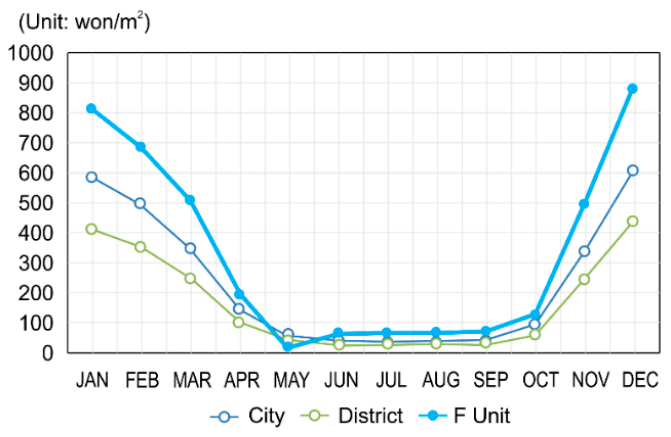

(a)

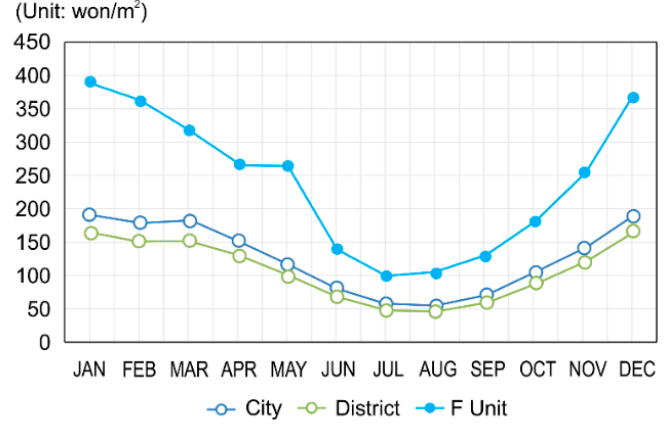

(b)

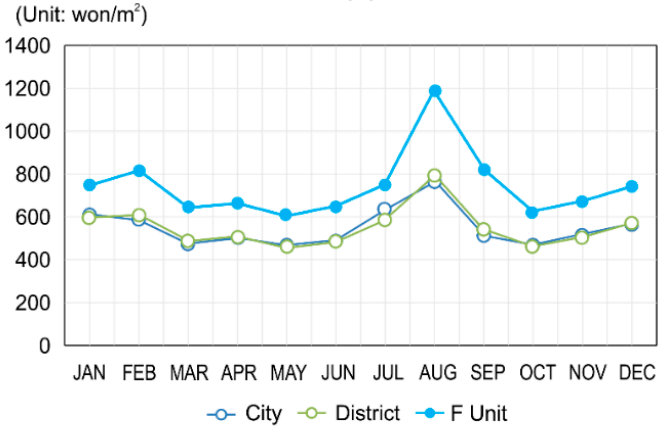

(c)

Figure 9. Energy consumption of unit F. (a) Heating bills; (b) Hot water bills; and (c) Electricity bills.

\subsection{Discussion}

When the maintenance cost for one year was investigated to identify the energy efficiency grade or the energy consumption of the six G-SEED-certified units with incentives, the amount of energy use of some units was smaller than that of the surrounding units, but others had higher energy consumption than the surrounding units. In total, energy consumption was higher than the average of the city or district, as shown in Table 6. Based on the annual average data of heating, hot water, and electrical energy consumption for the estimation of energy consumption, Table 6 compares the average values of the units with the values of the surrounding units, district, and city. The gap differences are shown with $\uparrow, \uparrow \uparrow$, and $\uparrow \uparrow \uparrow$. The data indicate that unit A consumed less energy for heating and hot water than the surrounding units, and the energy consumption for hot water and electricity of unit B was lower than that of the surrounding units. All the other units showed higher values when compared with the average energy consumption of the surrounding units, district, and city.

The G-SEED certification confirms that the buildings were constructed to facilitate high energy efficiencies. Thus, Table 6 indicates that problems developed because the buildings were not properly managed in terms of actual energy consumption. Therefore, maintaining the energy efficiency of G-SEED-certified buildings requires continuous management with respect to actual energy consumption. 
Table 6. Analysis of energy consumption in the six units.

\begin{tabular}{cccccccccc}
\hline & \multicolumn{3}{c}{ Heating } & \multicolumn{2}{c}{ Hot Water } & \multicolumn{2}{c}{ Electricity } \\
\cline { 2 - 9 } & $\begin{array}{c}\text { Surrounding } \\
\text { Unit Average }\end{array}$ & $\begin{array}{c}\text { District } \\
\text { Average }\end{array}$ & $\begin{array}{c}\text { City } \\
\text { Average }\end{array}$ & $\begin{array}{c}\text { Surrounding } \\
\text { Unit Average }\end{array}$ & $\begin{array}{c}\text { District } \\
\text { Average }\end{array}$ & $\begin{array}{c}\text { City } \\
\text { Average }\end{array}$ & $\begin{array}{c}\text { Surrounding } \\
\text { Unit Average }\end{array}$ & $\begin{array}{c}\text { District } \\
\text { Average }\end{array}$ & $\begin{array}{c}\text { City } \\
\text { Average }\end{array}$ \\
\hline $\mathrm{A}$ & $\downarrow$ & $\uparrow \uparrow \uparrow$ & $\uparrow \uparrow \uparrow$ & $\downarrow$ & $\uparrow \uparrow$ & $\uparrow \uparrow$ & $\uparrow$ & $\uparrow \uparrow$ & $\uparrow \uparrow \uparrow$ \\
$\mathrm{B}$ & $\uparrow$ & $\uparrow$ & $\uparrow \uparrow \uparrow$ & $\downarrow$ & $\uparrow$ & $\uparrow \uparrow \uparrow$ & $\downarrow$ & $\uparrow \uparrow \uparrow$ & $\uparrow \uparrow \uparrow$ \\
$\mathrm{C}$ & $\downarrow$ & $\downarrow$ & $\uparrow \uparrow$ & $\downarrow$ & $\uparrow$ & $\uparrow \uparrow \uparrow$ & $\downarrow$ & $\uparrow \uparrow$ & $\uparrow \uparrow$ \\
$\mathrm{D}$ & $\downarrow$ & - & $\uparrow$ & $\uparrow$ & - & $\uparrow \uparrow$ & $\downarrow$ & - & $\uparrow$ \\
$\mathrm{E}$ & - & $\uparrow$ & $\uparrow \uparrow \uparrow$ & - & $\uparrow \uparrow \uparrow$ & $\uparrow \uparrow \uparrow$ & - & $\uparrow \uparrow \uparrow$ \\
$\mathrm{F}$ & - & $\uparrow \uparrow \uparrow$ & $\uparrow \uparrow$ & - & $\uparrow \uparrow \uparrow$ & $\uparrow \uparrow \uparrow$ & - & $\uparrow \uparrow \uparrow$ & $\uparrow \uparrow \uparrow$ \\
\hline
\end{tabular}

Note: $\uparrow \uparrow \uparrow:$ Average gap of +100 points higher. $\uparrow \uparrow:$ Average gap of +50 points higher. $\uparrow:$ Average gap of below +50 points. $\downarrow$ : Average gap of -50 points higher. $\downarrow \downarrow$ : Average gap of below -50 points. $\downarrow \downarrow \downarrow$ : Average gap of below -100 points. - : No value.

Especially, in the case of the six-unit survey targets, G-SEED authentication of environmentally friendly buildings is available, since certification was less than a decade ago. Additionally, since all the survey target units received cost and institutional incentives, there can be economic concerns if the energy usage is not maintained after certification. Therefore, it is necessary to steadily manage buildings that are certified by G-SEED during the actual use stage, making it necessary to institutionally supplement energy efficiency management.

\section{Improvement Plan to Increase Energy Efficiency in Apartments}

\subsection{Analysis of Energy Management System in South Korea (G-SEED)}

In South Korea, the apartment housing management law was enacted on 12 August 2016 to decide on issues that need to be managed in apartment houses and ensure that apartment houses are managed transparently, safely, and efficiently. Apartment houses with 150 or more households have to be managed obligatorily and should submit the data demanded by the AMIS. The relevant content means that all the information related to the management of apartment houses, including information about the units, maintenance costs, record of maintenance and management, bidding, energy use, audits, and housing transfer dates, amongst others, are registered, saved, and managed in the system.

When a user accesses the AMIS and chooses a unit using the legal Dong or road name, the maintenance costs, records, current state of maintenance and management, and bidding rates of the relevant unit can be checked in addition to basic data. In the category of green/energy information, data regarding the G-SEED certification status and acquired energy consumption grade are linked. Most of the units had G-SEED certifications, but the information was not updated properly. Since the enactment of the green architecture law, the energy use grade certification must be attached for a real estate deal, but, since notification is not compulsory, it was hard to find instances of publication except for units with high grades.

\subsection{Analysis of Energy Efficiency Management Systems Internationally}

\subsubsection{Efficiency Guidelines for Buildings in the European Union (EPBD)}

The E.U. enacted "the revised bill (plan) of the guideline about a building's energy efficiency, 2002" and discussed the concept of "carbon dioxide emission and the building whose primary energy consumption is small or close to zero (finally defined as 'an energy-zero building') through reduction of greenhouse gases and energy security policies" [35]. In particular, beyond "an energy-zero building", stricter requirements to guarantee the supply of energy-zero buildings were proposed, which would ensure that by 31 December 2018 all new buildings in the E.U. are energy-zero buildings [36].

Furthermore, the existing standard for buildings over $1000 \mathrm{~m}^{2}$ has been removed, and all of the buildings have been included. Facilities have to be upgraded to match the present standards. Plans for optimal expenditure and expanded investment for the improvement of energy efficiency have been included. The amendment of the revised plan on buildings' energy efficiency guidelines was approved 
on 23 April 2009, and relevant content was enacted as new guidelines in 2010. Figure 10 illustrates the energy performance grade certification that was issued by the E.U., which offers information about energy efficiency and carbon dioxide emissions of the relevant building. It should be checked by both the buyer and lessee in case of a real estate deal. The energy performance certificate (EPC) consists of two types of information, namely information about housing energy consumption and recommendations for improving energy efficiency, as shown in Figure 11.
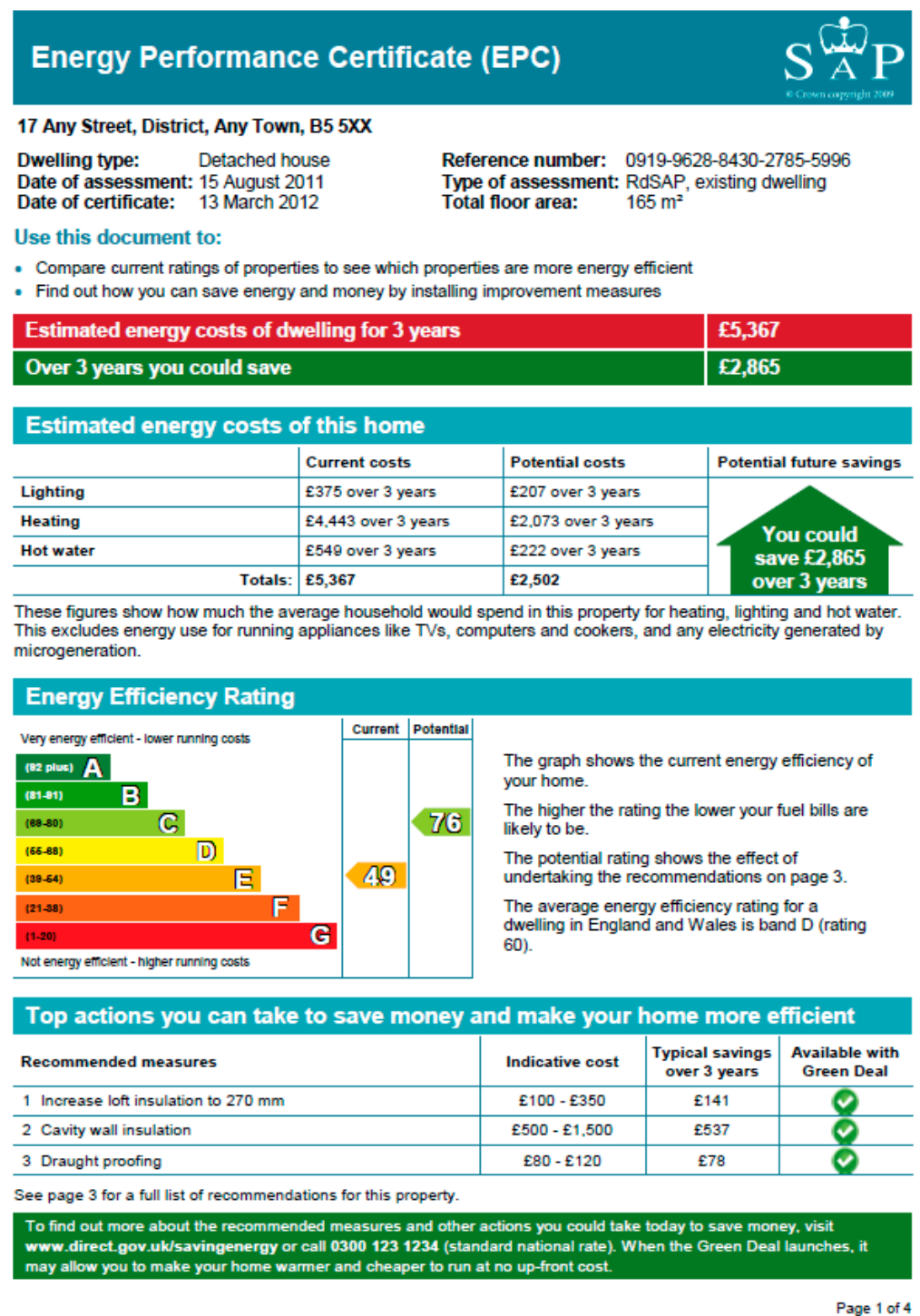

Figure 10. Example of an energy performance certificate for a new home [37]. 


\begin{tabular}{|l|c|c|c|c|}
\hline Recommended measures & Indicative cost & $\begin{array}{c}\text { Typical savings } \\
\text { per year }\end{array}$ & $\begin{array}{c}\text { Rating after } \\
\text { improvement }\end{array}$ & $\begin{array}{c}\text { Green deal } \\
\text { finance }\end{array}$ \\
\hline Increase loft insulation to $270 \mathrm{~mm}$ & $£ 100-£ 350$ & $£ 47$ & E 51 & \\
\hline Cavity wall insulation & $£ 500-£ 1,500$ & $£ 179$ & D 59 & \\
\hline Draught proofing & $£ 80-£ 120$ & $£ 26$ & D 60 & D \\
\hline Low energy lighting for all fixed outlets & $£ 50$ & $£ 43$ & D 61 & \\
\hline $\begin{array}{l}\text { Replace boiler with new } \\
\text { condensing boiler }\end{array}$ & $£ 2,200-£ 3,000$ & $£ 339$ & C 74 & \\
\hline Solar water heating & $£ 4,000-£ 6,000$ & $£ 34$ & C 75 & \\
\hline $\begin{array}{l}\text { Replace single glazed windows } \\
\text { with low-E double glazing }\end{array}$ & $£ 3,300-£ 6,500$ & $£ 41$ & C 76 & \\
\hline
\end{tabular}

Figure 11. Example of energy efficiency relation information [37].

The purposes of issuing an EPC, are, firstly, to induce a building's or house's retrofit by providing information about the building's energy performance, and, secondly, to boost investment in energy efficiency by offering reliable information about a building's energy performance to the real estate market. An EPC not only provides information about a building's or house's performance, but also about, for example, the cost of the means used to improve housing efficiency (insulation reinforcement, exchange of windows and doors, and change to a high-efficiency boiler, amongst others), yearly amount of saved energy, and financial support from the government for different means to improve housing efficiency.

\subsubsection{Major Industrial Countries (U.S.A. (Energy Star), Japan (CASBEE))}

The U.S.A. and Japan are conducting diverse programs for building energy efficiency, but systematic sanctions are not being imposed on inefficient energy use, except for the certification of energy efficiency grades [4-6,27-30].

\subsection{Improvement Plan for Energy Efficiency Management System of Apartments}

The current AMIS provides energy consumption information only, and efficient follow-up management is not being conducted. Domestic energy efficiency management will be feasible if systematic management is conducted by applying international energy management systems.

The analysis of domestic and foreign energy efficiency management systems shows that the AMIS currently operated in South Korea offers only information about the present state by ordering management offices to collect information and submit it to the system when users consume energy. Compared to the energy efficiency management system of the E.U., specific energy consumption and grades, amount of carbon dioxide emissions, potential to save energy, and other parameters are not present in the South Korean system. In addition, in the case of apartment houses under repair, records and the current status of their maintenance and management are available to the public, but the duration of each construction type is announced without information regarding their age. Thus, it is difficult for users to recognize whether energy consumption is high or low using the AMIS, and its consumption is not managed well. Thus, the system should be enhanced based on other international systems.

If a real-time energy efficiency management system is implemented by adopting the advantages of EPBD, energy will be effectively managed in the future through the "energy efficiency management system of apartments" in South Korea. On this basis, an improvement plan for supplementing the energy efficiency management system of apartments is shown in Figure 12. 


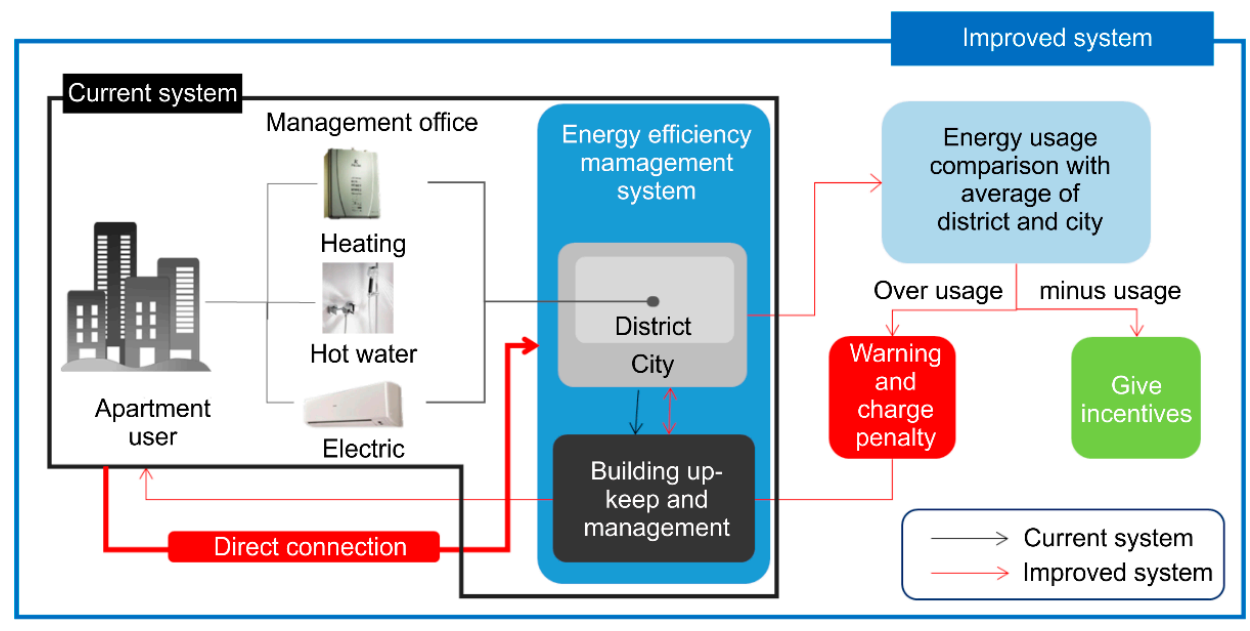

Figure 12. Improvement plan for energy efficiency AMIS.

Figure 12 presents measures for improving the present approach to the AMIS. Users themselves can access data regarding energy consumption and maintenance costs, amongst others, about the units. They can access information about the average energy consumption of the apartment house, relevant district, and city. Moreover, when energy use is higher than the average of the district or city, it is restricted and penalized. When energy use is lower than the average, incentives, such as tax exemption, are offered; energy consumption can thus be regulated. Furthermore, a building hardware management system can be operated simultaneously for the maintenance and management of apartment houses to manage the building's energy efficiency system along with the building itself.

\section{Conclusions}

This study aimed to determine the reality of energy efficiency management of apartment houses that obtained high energy efficiency grade certification for G-SEED and related incentives in South Korea. It also highlights the necessity of upgrading the AMIS and suggests improvement measures. After investigating only six apartments, we cannot definitively determine that the post-management of all G-SEED apartments is sluggish, but most of the target units showed a higher usage rate than the city's and district's average energy consumption. Therefore, this could confirm that the institutional formulation and management of buildings that received G-SEED certification were not done.

Energy usage management of AMIS apartments that are currently under operation is desirable, but the simple act of disclosing energy usage does not result in sanctions or rewards for high or low usage. Therefore, the current AMIS energy management system must be improved through complementary systems. Analysis of domestic and foreign energy efficiency management systems helped us to understand the real state of energy use in the South Korean AMIS. Based on this, specific measures to enhance efficiency, such as energy use grade degrees, energy saving potential, and carbon dioxide emissions reduction, are necessary.

As energy efficiency is becoming increasingly important, the South Korean government is creating a policy for zero-energy housing, which will have a system of producing and consuming energy on its own (a zero-energy building certification system was implemented in January 2017). Furthermore, zero-energy buildings are gradually becoming compulsory. The government should recognize that, even after apartment houses were built to maximize energy efficiency through G-SEED certification, poor follow-up management has led to poor management of energy consumption. After G-SEED certification, excess energy usage will result in economic losses, while reduced energy usage through sanctions will result in the relaxation of the floor area ratio or a cost incentive, like tax reductions. This study suggests that G-SEED buildings must publish their energy efficiency properly by enhancing the AMIS established to manage it. 
There are a few limitations to this research. By considering different characteristics, analyzing the area per household, income level, residential staff, etc., it is possible to grasp more accurate forms of energy usage and problems. But, in order to compare the G-SEED-certified buildings' energy usage with the average usage of a city or county district, we had to limit our analysis to only that based on the energy usage per dedicated area. Due to restrictions in obtaining relevant information, we were not able to use international units. As more buildings are certified by G-SEED in the future, we will be able to overcome some of these limitations with more thorough sample availability.

Author Contributions: Conceptualization, H.K.; Methodology, H.K. and W.P.; Software, H.K.; Validation, H.K. and W.P.; Formal Analysis, H.K.; Investigation, H.K.; Resources, H.K.; Data Curation, H.K.; Writing-Original Draft Preparation, H.K.; Writing-Review \& Editing, H.K. and W.P.; Visualization, H.K.; Supervision, W.P.; Project Administration, H.K.; Funding Acquisition, H.K. and W.P.

Funding: This work was supported by the National Research Foundation of South Korea (NRF) grant funded by the South Korean government grant number [NRF-2017R1D1A1B03027921].

Acknowledgments: This work was supported by the National Research Foundation of Korea (NRF) grant funded by the Korean government (No.NRF-2017R1D1A1B03027921) and the center for Women In Science, Engineering and Technology (WISET) Grant funded by the Ministry of Science, ICT \& Future Planning of Korea (MSIP) under the Program for Returners into R\&D.

Conflicts of Interest: The authors declare no conflict of interest. The funders had no role in the design of the study; in the collection, analyses, or interpretation of data; in the writing of the manuscript, and in the decision to publish the results.

\section{References}

1. United Nations Framework Convention on Climate Change, The Paris Agreement. Available online: http:/ / unfccc.int/paris_agreement/items/9485.php,2018 (accessed on 7 June 2018).

2. Ministry of Land, Infrastructure, and Transport (MOLIT). POST-2020 Planning on Development of Greenhouse Gas Reduction in Building Sector; MOLIT: Sejong-city, Korea, 2016.

3. Office for Government Policy Coordination; Prime Minister's Secretariat; Greenhouse Gas Inventory \& Research Center. National Greenhouse Gas Inventory Report of Korea; Office for Government Policy Coordination: Seoul, Korea, 2016.

4. Building Research Establishment (BRE). Environmental Assessment Method, BREEAM New Construction Technical Manual; BRE: Hong Kong, China, 2011.

5. United States Green Building Council (USGBC). LEED Reference Guide for Building Design and Construction; USGBC: Washington, DC, USA, 2013.

6. United States Green Building Council (USGBC). LEED v4 User Guide; USGBC: Washington, DC, USA, 2014.

7. Ministry of Land, Infrastructure, and Transport (MOLIT). Law of Supporting Green Building; Ministry of Government Legislation; National Law Information Center: Sejong-city, Korea, 2016. Available online: http: / / www.law.go.kr/lsSc.do?menuId=0\&subMenu=1\&query=\%EB\%85\%B9\%EC\%83\%89\%EA\% B1\%B4\%EC\%B6\%95\%EB\%B2\%95\#undefined,2016 (accessed on 24 September 2017).

8. Thatcher, A.; Milner, K. Is a green building really better for building occupants? A longitudinal evaluation. Build. Environ. 2016, 108, 194-206. [CrossRef]

9. Khoshbakht, M.; Goua, Z.; Lu, Y.; Xie, X.; Zhang, J. Are green buildings more satisfactory? A review of global evidence. Habitat Int. 2018, 74, 57-65. [CrossRef]

10. Jeong, J.; Hong, T.; Ji, C.; Kim, J.; Lee, M.; Jeong, K. Development of an evaluation process for green and non-green buildings focused on energy performance of G-SEED and LEED. Build. Environ. 2016, 105, 172-184. [CrossRef]

11. Ingrao, C.; Messineo, A.; Beltramo, R.; Yigitcanlar, T.; Ioppolo, G. How can life cycle thinking support sustainability of buildings? Investigating life cycle assessment applications for energy efficiency and environmental performance. J. Clean. Prod. 2018, 556-569. [CrossRef]

12. Tronchin, L.; Manfren, M.; Nastasi, B. Energy efficiency, demand side management and energy storage technologies-A critical analysis of possible paths of integration in the built environment. Renew. Sustain. Energy Rev. 2018, 95, 341-353. [CrossRef] 
13. Lee, J.; Shepley, M. Analysis of human factors in a building environmental assessment system in Korea: Resident perception and the G-SEED for MF scores. Build. Environ. 2018, 142, 388-397. [CrossRef]

14. Paone, A.; Bacher, J.P. The Impact of Building Occupant Behavior on Energy Efficiency and Methods to Influence It: A Review of the State of the Art. Energies 2018, 11, 953. [CrossRef]

15. Lee, N.; Tae, S.; Gong, Y.; Roh, S. Integrated building life-cycle assessment model to support South Korea's green building certification system. Renew. Sustain. Energy Rev. 2017, 76, 43-50. [CrossRef]

16. Chet, I.M.; Illa, S.; Tam, V.W.Y.; Le, K.N.; Shen, L. Key credit criteria among international green building rating tools. J. Clean. Prod. 2017, 164, 209-220. [CrossRef]

17. Shan, M.; Hwang, B. Green building rating systems: Global reviews of practices and research efforts. Sustain. Cities Soc. 2018, 39, 172-180. [CrossRef]

18. Geis, S.; Oster, D.; Mach, E. Transition towards Energy Efficiency: Developing the Nigerian Building Energy Efficiency Code. Sustainability 2018, 10, 2620. [CrossRef]

19. Dwai, L.N.; Ali, K.N. The economic benefits of a green building-Evidence from Malaysia. J. Build. Eng. 2018, 18, 448-453. [CrossRef]

20. Wu, X.; Peng, B.; Lin, B. A dynamic life cycle carbon emission assessment on green and non-green buildings in China. Energy Build. 2017, 149, 272-281. [CrossRef]

21. Enke, R.A.; Morrison, G.M. Analysis of the transition effects of building codes and regulations on the emergence of a low carbon residential building sector. Energy Build. 2017, 156, 40-50. [CrossRef]

22. Garcia, A.; Cumo, D.; Tiberi, F.; Sforzini, M.; Piras, V.; Cost-Benefit, G. Analysis for Energy Management in Public Buildings: Four Italian Case Studies. Energies 2016, 9, 522. [CrossRef]

23. G-SEED, Korea Green Building Certification System (G-SEED) Support System. Available online: http: / / gseed.greentogether.go.kr/sys/gms/selectGreenMain.do,2017 (accessed on 7 June 2018).

24. Statistics Korea, Building Status. Available online: http://www.index.go.kr/potal/main/EachDtlPageDetail. do?idx_cd=1226,2017 (accessed on 8 June 2018).

25. Apartment Management Info System. Available online: http:/ /www.k-apt.go.kr,2009 (accessed on 8 June 2018).

26. Oh, Y. Management Status and Suggestions for Improvement of Environment-Friendly Features in GBCS-Certified Apartment Communities. Master's Thesis, Chungbuk National, Cheongju, Korea, 2011. Available online: http:/ / www.riss.kr/link?id=T12368104 (accessed on 2 September 2018).

27. Kang, B. Management Status Analysis in GBCS Certified Housing Complexes. Master's Thesis, University of Seoul, Seoul, Korea, 2013. Available online: www.riss.kr/link?id=T13234955 (accessed on 2 September 2018).

28. Energy Star, Energy Star Overview. 2018. Available online: https:/ / www.energystar.gov/about (accessed on 4 April 2018).

29. Office of Air and Radiation, Climate Protection Partnerships Division, National Awareness of ENERGY STAR®for 2016, Analysis of 2016 CEE Household Survey. 2017. Available online: https:/ / www.energystar. gov/awareness (accessed on 4 April 2018).

30. CASBEE for New Construction, Technical Manual. 2014. Available online: http://www.ibec.or.jp/CASBEE/ english/download/CASBEE-BD(NC)e_2014manual.pdf (accessed on 4 April 2018).

31. United States Green Building Council. 2018. Available online: http:/ /www.usgbc.org/home (accessed on 25 March 2018).

32. EnergyPlus, Energy Plus Engineering Reference. 2015. Available online: https://energyplus.net/sites/ default/files/pdfs_v8.3.0/EngineeringReference.pdf (accessed on 4 April 2018).

33. Kim, M. Characteristics and determinants by electricity consumption level of households in Korea. Energy Repos 2018, 4, 70-76. [CrossRef]

34. Kim, H.; Park, W. A Comparison Analysis on the Changes in Energy Efficiency of the G-SEED Certified Apartment Buildings. J. Reg. Assoc. Archit. Inst. Korea 2016, 18, 171-182.

35. Yeong, J.; der Über, Y. Europäischen Instrumente zur Energieeinsparung im Gebäudebereich. Korean Environ. Law Assoc. 2011, 33, 167-198. 
36. European Commission, EU Action Against Climate Change: Leading Global Action to 2020 and Beyond. 2008. Available online: https:/ / ec.europa.eu/clima/sites/campaign/pdf/post_2012_en.pdf (accessed on 8 June 2018).

37. UK Government, Energy Performance Certificate. 2009. Available online: https://www.gov.uk/government/ uploads/system/uploads/attachment_data/file/49997/1790388.pdf (accessed on 26 June 2018). 